\title{
Monumental Landscapes and the Politics of Place: The First Lenin to Fall
}

\author{
Kateryna Malaia \\ University of Wisconsin-Milwaukee
}

\begin{abstract}
On August 1, 1990, there was an unprecedented event in the Ukrainian town of Chervonohrad: a crowd gathered at the central square and, for the first time in the USSR, demolished a monument to Lenin. The demolition caused a political scandal and was the first of a chain of Lenin statue topplings all over Soviet Ukraine and beyond. Chervonohrad's deconstruction is often compared to the array of Lenin statue demolitions that took place during the 2013-14 Ukrainian Revolution. Yet, this historic comparison does not answer the question: why was Chervonohrad, out of all the Soviet political centres and peripheral towns, meant to go down in history in this monumental way?

Although the transformation of monumental landscapes has been among the most studied aspects of the post-Soviet condition, it has often been approached unilaterally. The studies of dismantled monuments have explored the largest scale of national and international politics, national imageries, and historic myth. The overwhelming attention paid to major metropolitan areas overshadowed the importance of place politics, local actors, and power relationships within former Soviet republics. As a result, the transformation of Soviet monumental landscapes has been sometimes misread as a top-down geopolitical process over the plain and ghostly backgrounds of post-Soviet metropolitan cityscapes.

This article questions the scales and methods used to study monumental deconstruction. While national politics were undoubtedly an integral part of Chervonohrad's milestone event, this study aims to understand the complex causes that led to the removal of the monument through Chervonohrad's politics of place, the history of urban displacement and appropriation, and the agents and constellations that made this demolition possible.
\end{abstract}

Keywords: monumental landscapes, demolition, USSR, place politics, periphery.

\section{INTRODUCTION}

T enter Chervonohrad by the only existing freeway running between this coal mining town and the regionally-central city of Lviv. The newly constructed road gives me a first glimpse of the locals' ability to organize and change their city. My guide-an old friend who happened to have relatives in town-tells me about how horrible the road used to be prior to the 2013-14 Ukrainian Revolution: 
The caverns felt more like holes left by shelling, than anything that could have been done to the road from just driving and disrepair. But then locals blocked the road during the protests in Kyiv and demanded for it to be fixed, or they would have never let the local bureaucrats exit or enter the town. As you can see, the road is totally drivable now. (Iryna Sh.)

The freeway is surrounded by fields and patches of forest. Here and there you can see a house or two, some old barns, and a couple of horses out to pasture. Nothing but fields and trees until the moment we see a statue of a coal miner standing at the first crossroad since we left Lviv. The statue signifies the entrance to this Ukrainian town, which is only some 30 kilometers away from the Ukrainian-Polish border check-point.

The story that brought me to Chervonohrad is of great importance, but is not remembered much these days. Almost a year prior to the collapse of the Soviet Union and the subsequent rethinking of the former Soviet monumental landscapes, the Chervonohrad locals reshaped their monumental landscape in a momentous, yet unexpected, manner. Before any other Lenin statue was removed in the Soviet Union, before the central authorities called for the deconstruction of Lenin monuments, even before the Soviet Union fell apart, the dwellers of Chervonohrad decided that their Lenin statue must be no more.

On August 1, 1990, a crowd gathered at the main plaza of Chervonohrad. Several local and regional officials spoke to the crowd on the matter of demolition. Those against the demolition were muffled by people yelling at them. A video filmed on the day of demolition shows how the monument was removed with the help of municipal trucks and cranes ("Demontazh pam"iatnyka"). Some people attempted to live-shield the monument but the demolition supporters approached the monument from the other side. Soon the monument was removed and put in a truck. Those who were present at the square remember a few people running after the truck and throwing flowers into it, almost like at a funeral (Mariia Akimivna L.).

The news of Chervonohrad's Lenin statue demolition was a shock for everyone, including the pro-Ukrainian independence politicians in Kyiv and Lviv. The central authorities in Kyiv discussed the incident hours after the monument was demolished, and the rhetoric of the Ukrainian SSR Parliament that day showed how surprised the deputies were with the demolition ("Protokol zasidannia"). Some politicians called for punishing those responsible for the removal, yet no arrests or prosecutions were ever made.

News about the monument quickly spread to the Soviet Union and the world through Radio Svoboda, a leading news source that reported on the USSR but was not controlled by Soviet authorities. In the next days and weeks, several other Lenin statues were demolished in Western Ukraine, Latvia, Lithuania, and other Soviet republics. 
This story should not be perceived as simply a grassroots act of a national scale political rebellion; it was much more complex and localized. Unlike the famous 2013 Lenin statue toppling in Kyiv, demolition of the Chervonohrad Lenin statue took place before the collapse of the USSR, was supported by local officials, was initiated by the coal miners' union, and occurred at a place with a complex and turbulent history and memory. The following investigation concentrates on the context of place where this story occurred and is viewed from the perspective of a centre-periphery relationship and theories of space and place appropriation. Besides archival and secondary data, this research was facilitated with oral history investigations conducted in 2015. These combined methodologies are helpful in reflecting on the existing scholarship about the dismantling and construction of Soviet monuments. While honouring the results of existing research on monumental landscapes, this paper takes a close look at the Soviet political periphery, i.e., the Western Ukrainian city of Chervonohrad, to understand the ambiguity of the last years of the Soviet Union and the role of symbolic landscapes in the redistribution of power away from the large Soviet centres. In this study, the central political agenda gives way to small scale spatial politics and genius loci-the spirit of the place-to comprehend the creation and deconstruction of the symbolic landscapes.

This article rethinks the Chervonohrad statue demolition in three steps. First, it reviews Chervonohrad's history to understand the conditions of life in this town before it entered the process of de-Sovietization (prior to 1990). Second, it analyzes the position of Chervonohrad in the USSR and the implications of that position for the possibility of local scale self-governance. Third, it questions the politics of place to show how the unique position of Chervonohrad among Soviet cities and towns led to the demolition of the monument.

\section{Before CHERVONOHRAD BECAME CHERVONOHRAD}

The written history of the town now known as Chervonohrad (it was Krystynopil before 1951) begins in 1692, when Field Crown Hetman Feliks Potocki requested Magdeburg Right from the Polish king for his newlyfounded town Krystynopil. The town started from the castle and village homes of the Novyi Dvir settlement (first mentioned in 1613). The only facts known about the early village of Novyi Dvir is that in the time of Feliks Potocki, it already had an Orthodox church and a Catholic (Bernardine) church (Hrynyk and Iarosh-Zamois'ka 32).

The offspring of Potocki finished the construction of a luxurious palace and added a couple of churches and a monastery. Religious buildings and institutions shaped the fame of Krystynopil as a religious centre. The city 
grew on the western side of the palace, its residences alternating with religious institutions. The new development spatially bridged the old settlement of Novyi Dvir with the palace, and the new denser street structure extended the possibilities for trade. During the early 1700s, a flourishing Krystynopil attracted an extensive Jewish population. Jewish traders and craftsmen paid higher taxes and were, therefore, more profitable for the city rulers. By the second half of the eighteenth century, $75 \%$ of the town population was Jewish, the rest comprised Poles, Ukrainians, and Germans. Krystynopil happened to be at the edge of the territorial conflict between the Austro-Hungarian Empire and the Russian Empire; thus the city fell into decay as a result of the constantly changing ruling entity and adjacent battles during the second half of the eighteenth century.

Krystynopil resurged in the nineteenth century under the settled Austro-Hungarian Empire. The city's small industrial facilities and markets benefitted from the construction of new roads and, most importantly, a railroad that allowed the transportation of local goods to Poland. Most of the traders and manufacturers in the town were of Jewish origin. Jewish house owners had to pay for the main façade length. Most of the houses at the main plaza and on the streets of pre-World War II Krystynopil were tightly packed with narrow buildings widening to their backs. By the late nineteenth century, the majority of Krystynopil's buildings were made of stone, as in previous decades Krystynopil had experienced multiple devastating fires. In this way, Krystynopil entered the twentieth century built mostly of stone, complemented with several embellished baroque churches, minimalist Hasidic synagogues, and the classicist Potocki palace.

At the beginning of World War I, Krystynopil was conquered by the Russian army. The arrival of the Russians was signified by the first Jewish pogrom in the town's history (Hrynyk and Iarosh-Zamois'ka 190). In 1915, Austro-Hungarians returned the entire region of Galicia and the town of Krystynopil back to their empire. In the swirl of World War I events, AustroHungarian administration promised national autonomy to Ukrainian lands. In 1918, Lviv activists and politicians announced an independent WesternUkrainian Republic. Krystynopil became a part of this republic, yet was soon taken back by the Polish army. The return of the Polish administration was followed by repression of Ukrainian intelligentsia and clergy. Ukrainian soldiers, who had not left with the rest of the army, were hunted and taken to Krystynopil for execution. An attempt to create the Western Ukrainian People's Republic failed - the lands of Galicia fell under Polish control for the entire period between World Wars I and II.

The town life between the wars was not much different from what it had been earlier. The local Polish-Ukrainian relationship soon evened up: there were no ethnic conflicts or major tensions in the interwar period. The demographics of the town remained similar to what they were before 1914 . 
The Jewish community in 1939 numbered more than 2200 people out of a total population of around 5000, even though some families left for Palestine in the mid-1930s.

Krystynopil's destiny during World War II was, without exaggeration, tragic. In September 1939, the Soviet Army occupied large parts of Galicia, but did not take Krystynopil. The German Army entered the town on September 19. According to witnesses, a German scout was killed by someone in the city; as a result, overnight, the Germans burned all the Jewish houses, which was virtually the entire town (Hrynyk and Iarosh-Zamois'ka 213). The old village of Novyi Dvir became the only surviving part of town ("Novyi Dvir. Chervonohrad-Solokiia"). After that, the town was once again taken by the Soviets and returned to the Germans. The few remaining Jews who did not leave for the Soviet Union or emigrate elsewhere, were executed in 1941. Soon the signs of hundreds of years of Jewish life disappeared from Krystynopil-Germans deconstructed synagogues and the Jewish cemetery to build roads. The borderline between German and Soviet territories cut off Krystynopil's adjacent forest, so locals had to buy what was left of the old Jewish houses and use those materials for heating, finishing the job of erasing the local Jewish history.

After World War II, Krystynopil, which had already lost two thirds of its population, experienced a new wave of displacement. At first, under the agreement between the new Communist Poland and the Soviet Union, Krystynopil became a part of Poland. Beginning in the spring of 1945, many Ukrainians were deported from Krystynopil and surrounding villages. In 1946, the Polish administration deported Ukrainian dwellers of Novyi Dvir. As a result, by the end of the 1940s Krystynopil became a monoethnic Polish town.

In 1951, the USSR and Poland made a new exchange deal for the near border lands. According to this deal, the town of Ustrzyki Dolne and the surrounding territories went to Poland. Soviet Ukraine received the towns of Belz, Krystynopil, and surrounding territories. Once again, the population of Krystynopil had to leave overnight, this time in the direction of Poland. For 15 days, between November 1 and 15, 1951, the city was absolutely empty except for the displacement organizing committee working in the Basilian monastery. On November 15, people from the entire Soviet Union were allowed to move to Krystynopil. Only the original Krystynopil locals who were deported during the first post-World War II years were restricted from moving to the town.

Prior to World War II, large coal deposits had been discovered in the vicinity of Krystynopil. In 1951 the Soviet administration began developing these coal deposits with the construction of the first coal mineVelykomostivs'ka No. 2. At the same time, the town was renamed to a neutrally Soviet "Chervonohrad." Under this name the town started a new 
Soviet life as a coal mining settlement with a population of 1705 people (Hrynyk and Iarosh-Zamois'ka 213). The discovery of coal and the development of the coal industry largely defined the destiny of KrystynopilChervonohrad through the second half of the twentieth century and indirectly shaped the sequence of events that led to the demolition of the Lenin statue in 1990.

\section{SOVIET CHERVONOHRAD}

Chervonohrad, as seen from its pre-1951 history is no regular town. Its location in the liminal zone of several cultures (Ukrainian, Polish, Jewish, Russian, Austro-Hungarian) first facilitated the creation of its unique multicultural environment. However, during World War II, its borderline location played a cruel joke on Krystynopil-Chervonohrad-all of its multiculturalism and $100 \%$ of its population were erased and replaced by a very different public with lifestyles different from previous inhabitants. After 1951, many of those who arrived in Chervonohrad were associated with coal mining and came from the Donbas (Eastern Ukraine) and Podmoskovie (Moscow region) coal mining basins. The newcomers often had had completely different experiences of World War II and the USSR in general than those who moved to Chervonohrad from other parts of historic Galicia.

In contrast to the regional centre Lviv, where the new Soviet administration had to remove monuments and change street names to eradicate the memory of the displaced Polish population, KrystynopilChervonohrad had no monuments and no street names left to remove. Not much had survived in the old town besides the Basilian monastery, the Potocki Palace, St. Vladimir's Church, and multiple small road chapels characteristic of Western Ukrainian tradition. The religious buildings in Chervonohrad did not function after World War II- under the Soviets, all the remaining religious buildings were reused for practical purposes, such as warehouses or ancillary factory buildings. According to locals, the Soviet administration required post-World War II inhabitants of Chervonohrad to remove crosses from the remaining religious buildings (Mariia Akimivna L.). The reasons for salvaging the remaining religious buildings could have been many, starting from the practical necessity for indoor space in a mostly destroyed town or the decline of church deconstruction as a precedent in Soviet politics.

Starting in 1951, Krystynopil-Chervonohrad was gradually rebuilt and expanded to its current borders. The early stage of reconstruction materialized at the site of the pre-existing town. The old Jewish store front homes were replaced with standard Stalin era two story barracks. These 
buildings were built in all Soviet cities and towns after World War II. Very similar houses can still be found in postwar neighbourhoods of Kyiv, Tashkent, or Minsk. These buildings were often built to be communal at first and later were modified according to changes in the local and Soviet economy. Only in the late 1960s did the residential houses of Chervonohrad begin to be hooked up to natural gas networks (Marchenko and Kolobov 77). The Stalin era barracks were among the buildings supplied with natural gas years after construction. The later 1960s-80s multi-storey standardized houses, familiar to historians as Khrushchev era apartment blocks and improved plan blocks, were built to receive gas, water, and electricity networks.

New construction and the creation of a new town centre downplayed the prewar built buildings. One of the places that lost its importance was the former main plaza of Krystynopil-the open space in front of the Potocki Palace complex that used to host farmers' markets and fairs and originally consisted of one- and two-storey mixed use store front buildings. Before the war, the palace's spatial position played a role similar to the medieval feudal castle: the palace buildings symbolically overlooked the activities in the main plaza of Krystynopil. During the 1950s, the palace lost its "watchman" position when the construction of residential buildings at the plaza blocked the view from the palace. A contemporary, regular-width street aligned with one side of the old plaza carries the memory of the plaza in its nameSoborna Ploshcha (Cathedral Square). Otherwise, the area was completely redesigned with new buildings. A new standard Stalin era movie theatre distracted attention from the neighbouring St. Iurii's Church. Such movie theatres were constructed all over the USSR in the 1950s. A long, threestorey Khrushchev era school building was constructed right in front of the Potocki Palace, completely removing the palace from its significant visual position overlooking the town.

New construction continued northeast and southwest of the old town of Krystynopil. Neighbourhoods south of Chervonohrad's main street, Taras Shevchenko Avenue, were composed of Stalin era, two-storey residential houses. Neighbourhoods north of the main promenade were composed of Khrushchev-period apartment blocks. The southwestern part of Chervonohrad was constructed using the pre-existing street grid of Krystynopil (Figure 1).

Chervonohrad was built according to all canons of the post-Stalin Soviet urban planning genre. The perimeter street development principle was abandoned to accommodate free standing street development. Residential buildings were now recessed back from the street edge to make space for omnipresent green zones. The territory of the new Chervonohrad was clearly subdivided into several areas: residential housing, zones of industrial production, green recreational areas, and a zone of trade attached to the 
representational space of the main plaza of the new town. It was this new plaza that, after Khrushchev era construction, claimed importance and a major position in the town's hierarchy. It hosted a number of buildings of special significance, including the new standard movie theatre, the palace of culture, and the city administration building. Its seniority over all other plazas, such as the railroad station or the former Soborna Ploshcha next to Potocki Palace, was finalized by the 1977 construction of a Lenin monument, a sanctum of every Soviet urbanity (Oleshko).

Figure 1. Street grid of old town Krystynopil and contemporary Chervonohrad (image by Kateryna Malaia)

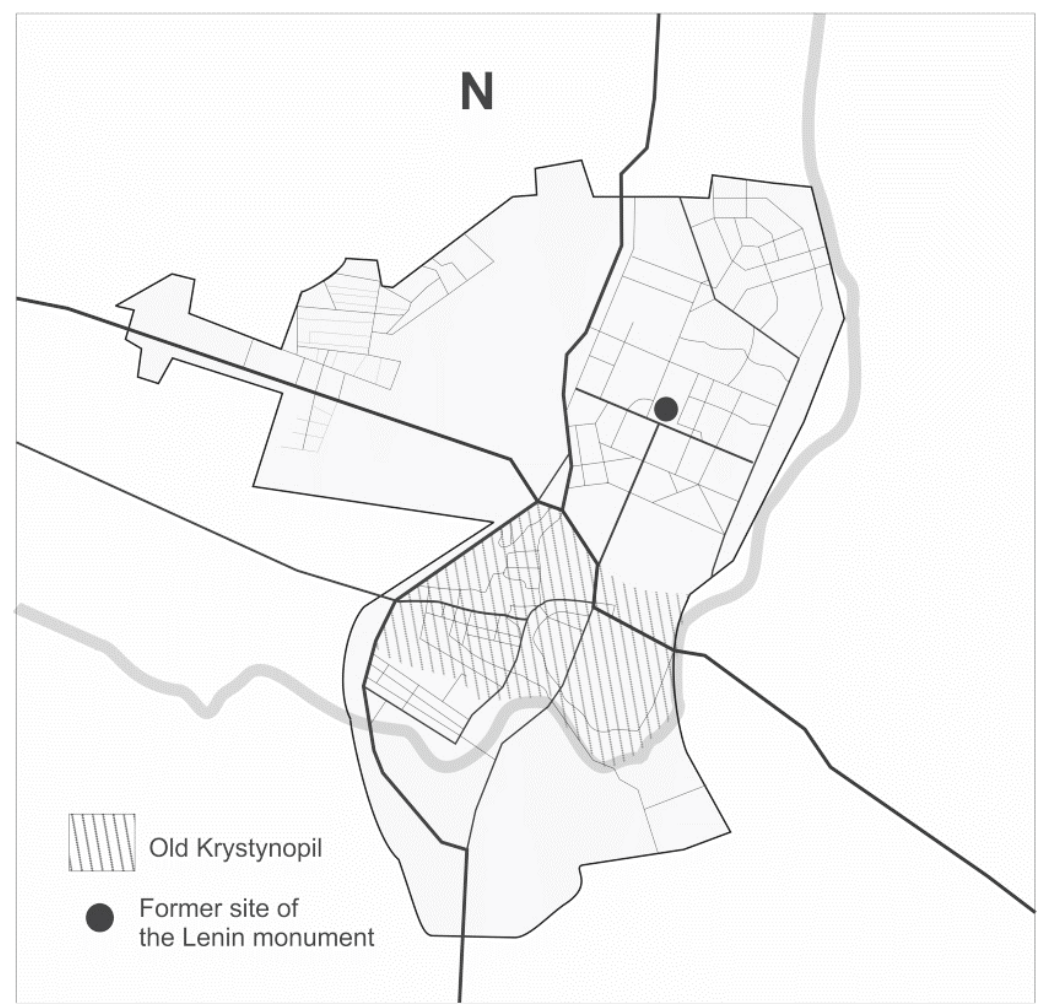




\section{THE END OF THE EXEMPLARY TOWN}

Until the late 1980s and the rise of the union strike movements, Chervonohrad performed as an exemplary socialist town (or sotsgorod, as it used to be called in the Soviet urban planning theory and practice). Ironically for the Soviet Union, by the late 1980s the political power in this industrial coal miners' town had shifted to the unions and workers. A large proportion of city council deputies were union members, and others who represented democratic political parties were highly willing to co-operate with the coal miners. In the late 1980s, union movements became very powerful political players in Eastern European socialist states and even inside the Soviet Union. In Poland the movement called Solidarnosc gained enormous popularity and virtually led the country through its passage away from the USSR (Repa). In Romania, workers' movements were responsible for the original outrage against Nicolae Ceaușescu and, indirectly, for the toppling of Lenin's monument on March 5, 1990.

Coal miners in the two Ukrainian coal mining regions were not satisfied with their situation either. The unsatisfactory rates of salary and social benefit increases led them to make demands to the central government of the Ukrainian SSR and the Soviet Union for more economic security. The demands of the Eastern Ukrainian, Donbas miners were first limited to economics. Meanwhile, the Western Ukrainian miners joined forces with political movements (such as Rukh) advocating for the sovereignty of Ukraine and against Soviet rule (Rusnachenko 127). Under the influence of local Rukh politicians, coal miners of Chervonohrad pushed through several political changeovers that neither Rukh nor the Chervonohrad strike committee would have been able to realize as quickly without each other.

On July 20, 1990 the city council of Chervonohrad voted on a new round of union demands. After a brief discussion of the union's economic requests, the deputies got to the most immediate political agenda-the removal of Lenin's monument from the town's main square, requisition of spaces in the town's administrative building that contained Communist Party offices, and the removal of all communist symbols around the town ("Protokol pozacherhovoi sesii"). The Chervonohrad city deputy from the first democratic convocation, Vasyl' Rozluts'kyi, a dissident and a member of $R u k h$, later explained that it was he who suggested the removal of the Lenin monument to the coal miners' strike committee. According to Rozluts'kyi, the workers enthusiastically agreed to add removal of the Lenin statue to their economic demands, after they realized the deputy was willing to take responsibility for the demolition (38). According to the head of the strike committee, Serhii Besaha, the monument removal was the only political point on the list of otherwise economic demands (Zharchyns'ka). 
The decision was finalized on July 31, 1990. After a heated discussion with the representatives of regional authorities, the town's council decided to take the Lenin statue down ("Protokol pozacherhovoi sesii"?). Rozluts'kyi stated that the city council started receiving threats from regional and republican centres, so they rushed to demolish the monument the next morning (38). The statue of Lenin was taken down in less than one day, on August 1, 1990.

The next day, August 2,1990, the Chervonohrad event was already being discussed by the Supreme Council of the Ukrainian SSR in Kyiv. The moods there were very different from those of Chervonohrad city officials; even the most anti-communist politicians were surprised at the speed with which the events unfolded ("Protokol zasidannia"). The deputies and the central government in Kyiv and Moscow were puzzled as to what to do with the situation. The Lenin monument was not demolished by a mob of proWestern students, the stereotypical anti-Soviet protesters in the eyes of the Communist Party. On the contrary, the monument was demolished after an official decision and under the supervision of the town's elected authorities, most of them being representatives of the Soviet backbone-the working class.

While it was performed in the midst of the evolving Soviet crisis, the demolition decision was discussed officially by a local group of authorities. Unlike other early Lenin memorial demolitions (Gaidai 139-40), it did not occur at a republican or even regional centre, but rather at the periphery of the Soviet Union with its complex cultural, political, and spatial history. Moreover, Chervonohrad had multiple other Soviet monuments that remained untouched until nowadays and are still admired by the locals, or that were removed quietly much later in the history of the independent Ukraine. Considering these circumstances, how should we understand the reasons for and meanings of this rupture in the monumental cityscape?

\section{WHY CHERVONOHRAD?}

The story of the fallen Lenin monument exists in-between two clusters of knowledge: the construction of national politics, national identity, and national memory as seen by the fields of cultural geography and political history, and the field of space and place studies. These perspectives are radically different in terms of the scale of inquiry. The questions of common political and social mythology present in landscapes and cityscapes drove most of the research on post-Soviet symbolism and are still dominant in the construction of post-Soviet monumental landscapes. For instance, Dmitri Sidorov discussed the relationship between symbolic Russianness and Russian architecture after the collapse of the USSR. Forest and Johnson 
wrote about the role of national memory and historic imagery in monument construction. Diener and Hagen observed the shift in cultural politics as represented by the urban planning and monumental landscapes of postSoviet cities. Some of these studies, Forest and Johnson's works in particular, directed attention to political actors, their interests, and their use of ideologies and myth to state their political interests. Yet, even the nuanced studies that consider local political actors barely expand beyond large metropolitan areas and the power play and political agendas as seen in regional and state centres. Chervonohrad event was not anticipated by central political powers in Kyiv and Moscow; until this day it is overlooked by scholars, working on the nation-scale politics and centralized narratives. The lack of interest in developments at the periphery gives the impression that shifts at the periphery take place in the image and likeness of the centre. Yet, the history of the late Soviet monumental deconstructions shows a different dynamic.

The many studies on the destiny of Soviet monumental landscapes predominantly ascribe the deconstruction of a monument as a radical phenomenon: either as a top down political decision or a bottom up outburst of identity mismatch between the population and its authorities. Yet, decimation of the Lenin monument did not match either the top-down or the bottom-up model of change. The decimation of the Lenin statue in Chervonohrad shows how different from mainstream politics the politicosymbolic relationship may become within specific power relations and complex place histories. This study looks at the regional and local spatial politics, along with the methods of place and space analysis, in order to describe the complex causation of the 1990 Chervonohrad events.

At the first glance, the 1990 Chervonohrad deconstruction of the Lenin statue may seem to be a part of the post-Soviet series of deconstructions of communist monuments. However, the only true similarity that Chervonohrad events have with the rest of post-Soviet deconstruction is the fact of the physical removal of the monument itself. The reasons for, the performance of, and the outcomes of this deconstruction appear to be very different from all other well-studied cases. In the Georgian city Gori, where the statue of Stalin was removed in 2010, the administration no longer required active public consent due to the 2008 Georgian-Russian war (Diener and Hagen 487). In the case of the Chervonohrad 1990 Lenin statue removal, the city administration also did not require clear and broad public approval, yet the statue removal was not because of recent tragic events. The role of the general public, namely, the support of the administration's decision, was shown by the representatives of the coal miners' union and strike committee. Instead of a stereotypical crowd of protesters, it was the coal miners who provided the political request for the demolition to the city council and the public presence and support at the plaza on the day of the 
event (Zharchyns'ka). According to the local newspaper, opinions regarding the Lenin statue demolition differed. Some citizens thought the removal was necessary, some wanted to save the monument as a form of historic heritage, and some thought the demolition was insane. Supporters of the statue removal clearly pointed to the historical citizen displacements and repressions as reasons for the monument to be removed (Bondaruk).

The range of opinions found at the square on the day of the demolition underlines the importance of the coal miners' union and strike committee as the representatives of the "public," even if this public excluded communist or moderate voices. Why were the coal miners so important to this political event? In the late 1980s the coal miners' strike movement gained enormous momentum due to several factors. First, the coal miners were a privileged group among Soviet workers. While all workers were supposed to be the political backbone of the Soviet system, the coal miners received higher pay, better social security, and more benefits than other workers, as labour in the coal mines was considered particularly hazardous and unhealthy (Matthews 31). In the mid-1980s the Soviet state could no longer keep up with the rates of increasing pay and benefits to the coal miners, and the resulting economic demands caused the rise of a strike movement. The common coal miners' status, identity, and interests allowed for an unprecedented co-operation between coal industry workers in Eastern and Western Ukraine, further empowering a cross-regional and even cross-cultural movement (Ahapov 23-26). Democratic and nationalist organizations actively co-operated with the coal miners' movements, recognizing their political momentum and implanting political goals into their earlier purely economic demands (Ahapov 27-40).

Unlike in Western Ukraine, in the East political collaborations between the coal-miners' strike committees and democratic movements were not as successful. In particular, politicization of Eastern Ukrainian coal miners did not result in the removal of Communist monuments. The 1990 election results in Eastern and Western Ukraine and the overall voter mobilization differences cast light on the polarity of political attitudes in these regions. In 1989-90 under the general course of perestroika reforms, campaigns of republican and local councils for election to the Supreme Soviet of the USSR took place according to a reformed system: voters were no longer offered just one candidate appointed by the Communist Party, they were also offered a number of candidates proposed by local organizations and electors at public meetings (Lane 66). This created a possibility for the candidates not affiliated with the Communist Party to be elected in places like Chervonohrad, where state politics were not as strong as those in Moscow or in republican centres (Rozluts'kyi 38). These new deputies carried a very different ideology from that of the central Communist authorities. 
The Western Ukrainians energetically reacted to cases of Communist Party interference with the election; as a result, they elected predominantly democratic local governing authorities (Birch 1145-54). Eastern Ukrainians showed less interest in the election, and the Communist Party was able to effectively use its administrative resource to influence the election outcomes. As a result, although some democratic candidates were elected to the Eastern Ukrainian local governing institutions, the Communists retained a majority. Despite the similarities in coal miners' strike movements, the Lenin statue demolition in Chervonohrad could not have taken place in any similar town in the Eastern Ukrainian coal basin because political actors willing to alter their monumental symbolic landscapes were absent.

Besides the administrative and "public" will, a concept that comes in handy when looking at Chervonohrad's statue demolition is the idea of a "periphery." Although the term varies along different disciplines, a centreperiphery dichotomy, which grew out of cultural geography and postcolonial studies, has been useful in studying economic and social networks. In the last couple of decades, the concept of a periphery became widely used in the humanities and humanistic social sciences due to the potential of a periphery to host (or produce) change. Despite its extreme breadth, the concept of a periphery and its relationship to and influence on a centre remains an incredibly helpful instrument in the analysis of political, spatial, social, and historical conditions.

Specialists in Soviet and Eurasian history have effectively used the centre-periphery concept to explain the specifics of Soviet periphery performances. In particular, Susanne Birgerson states that the centreperiphery relationship is held together by a number of actors and agencies"the rulers in the center and the imperial administrators in the periphery" (28). As soon as one of these links deforms or breaks the political power of the centre, the periphery cracks (Birgerson 22-23). The centre may still stand unchanged, while the imperial administrators are removed from the periphery, allowing for a rapid transformation of local politics.

Yet another demolition of a Lenin statue, also initiated by the city administration, took place in a Western Ukrainian centre-Ternopil-a week after the event in Chervonohrad. Why was it that the regional centre (Ternopil) demolished a Lenin monument after a less politically significant town (Chervonohrad), not the other way round? The Ternopil city council made a decision to remove the Lenin monument on July 18, 1990, but realization of the removal took much longer due to lack of support from the local industry and because of the much closer control over Ternopil events from the republican centre in Kyiv, and thereafter from Moscow (Gaidai 140). In Chervonohrad, the actions and reactions of the Communist Party occurred only in the aftermath of a quickly realized demolition ("Protokol zasidannia"). 
Chervonohrad's more distant relationship to a governing centre, the resulting opportunity to self-govern, and the presence of the coal mining industry, all played roles in the unfolding of the 1990 events. The state-level politics paved way to the Chervonohrad statue demolition by first freezing the habitual benefits of the local leading (and only) industry and then by allowing a relatively free election. Just like in Birgerson's argument about state politics at the periphery, the political outburst of the Lenin statue demolition was possible because of the local administrators-the connective link between the centre and the periphery-and the local working class, dissatisfied with the cut in their privileges. The local administrators who came to power after the free election were not loyal to the central government, they were loyal representatives of the periphery where they belonged. This shift reduced the power of the centre over the periphery to the extent that the citizens of Chervonohrad were able to commit the worst possible Communist blasphemy-demolish their statue of Lenin.

\section{INSTEAD OF LENIN AND COMMUNISTS}

The Chervonohrad monument to Lenin was removed with an official strategy to replace it with a monument to the Ukrainian poet Taras Shevchenko ("Protokol pozacherhovoi sesii"). This replacement agenda may seem surprising, considering that a monument to Shevchenko already existed in Chervonohrad at a different location. Shevchenko, a nineteenthcentury Ukrainian poet, was largely accepted and even somewhat canonized by the Communist Party due to his antibourgeois position, despite his clear Ukrainian nationalist and anti-Russian ethos. Monuments to the poet were reproduced around Ukraine in a manner similar to the mass produced Lenin statues, but in lower numbers, which raises the question of whether the placement of Shevchenko instead of Lenin was about the Shevchenko persona per se or about the replacement of a symbol on an empty pedestal. The new Chervonohrad administration condemned Lenin as the "slaughterer of the Ukrainian people" ("Protokol pozacherhovoi sesii"). Yet, they did not plan to install a monument that would be truly unacceptable to the Soviets, such as a Ukrainian freedom fighter (Stepan Bandera or Roman Shukhevych would be an example).

The choice of a poet acceptable to the Soviets possibly reflected a desire of the coal miners' strike committees and the city administration to solidify their newly gained power over the symbolic landscapes of the town. The stereotypical Soviet plaza could not have continued standing empty, devoid of any meaning other than that of a Soviet modernist urban planning project. The city council did not want to keep the pedestal empty as a reminder of the earlier powerful regime. The history of Chervonohrad-its nearly 
complete destruction during World War II and the complete repopulation and forced forgetting in the mid-twentieth century-created a need for a non-Soviet symbol. Perhaps more than in any other peripheral town of the Soviet Union, Chervonohrad was haunted by the fractional knowledge and memory of local pre-Soviet history. A monument to Shevchenko did later appear at the Chervonohrad main plaza, but in a different location. In the meantime, Lenin's location was taken over by a truly anti-Soviet symbol-a catholic cross dedicated to "the fall of the Soviet Empire and the declaration of an independent Ukraine" (Figure 3). The cross with a crucifixion, a traditional Western Ukrainian landmark, inevitably refers to Chervonohrad's Krystynopil past. More than would a monument to Shevchenko, it sends the viewer back to the time when Krystynopil had not yet grown to have a Soviet main plaza or a monument to Lenin.

Figure. 3. The Catholic cross that currently stands instead of the Lenin monument at the main Chervonohrad plaza (image by Kateryna Malaia).

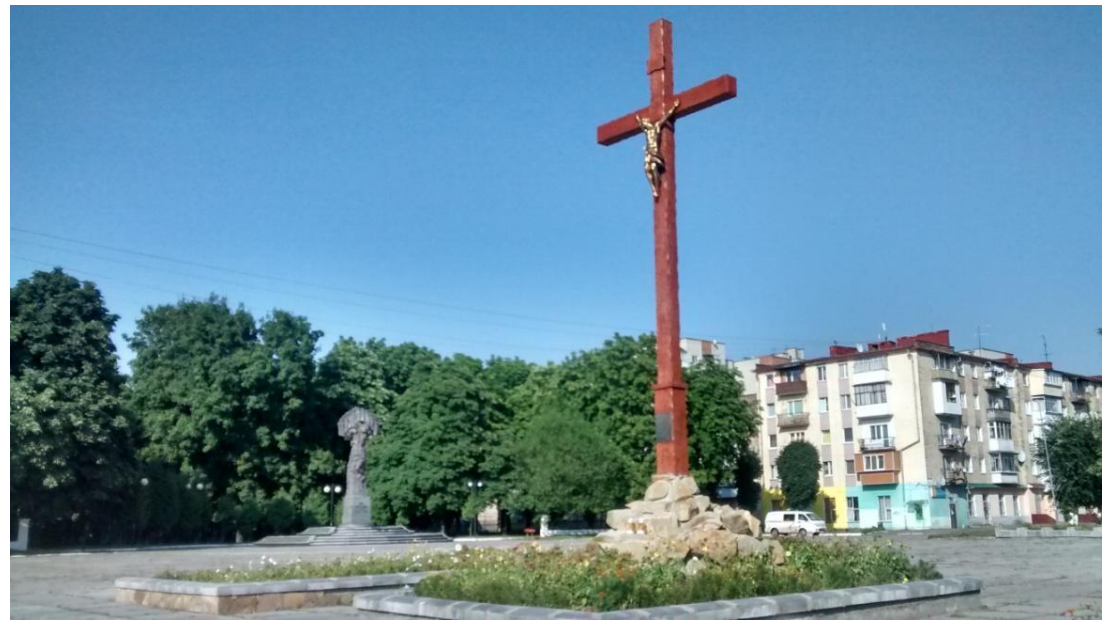

The Lenin statue demolition and the intention to construct a monument to Shevchenko were acts of placemaking-that is, they gave meaning to Chervonohrad and reconciled this meaning with non-Communist narratives of Chervonohrad history. Placemaking has been among the most popular concepts in the studies and creation of urban environments. However, this conceptual framework is usually used toward the construction of urban artifacts, not their deconstruction and replacement. For instance, Jeffrey Hou starts his 2010 Insurgent Public Space by listing the guerrilla art projects appropriating space in the nation-wide famous Seattle neighbourhood, Fremont (1). The spaces of Fremont are appropriated through creation, 
construction, and placement of the car-eating troll, Lenin's statue, a metal pig, and many other manifestoes of "insurgent placemaking" (Hou 1). Chervonohrad's new democratic administration had to appropriate the city through creating or recreating spatial meanings other than those of the Soviet time. However, as the centre of the city was deprived of rare remaining historic artifacts, they could not have undertaken an effort of reconstruction, as was popular in Ukraine in the early post-Soviet years. While clearly the result of a power play, rather than just a grassroots community effort, the Lenin monument removal and the subsequent construction of the cross and the monument to Shevchenko have all had traits of a positive value creation amidst the earlier Soviet symbolic landscapes that looked, felt, and were described as if nothing non-Soviet had ever existed in Chervonohrad (Marchenko and Kolobov 1-2).

Whether deliberately or not, the installation of a cross related Chervonohrad to the rest of the historic places in Western Ukraine, and even contemporary Poland where similar memorial crosses have become omnipresent in the last decades (Przybylska). While it may be argued that a cross could have arisen from Polish cultural influence communicated through the active cross border migration and cultural exchange, it may also appear to be indigenous to Chervonohrad because of the city's Polish past. Unlike Lviv, where a lot of the historic built fabric and small-scale markers, such as Polish mailboxes, were preserved, there are no longer noticeable traces of Polish everyday life in Chervonohrad. Nothing reminds the public that Poles were ever there except for two churches located far from the contemporary city that serve as ceremonial rather than everyday spaces for the townsfolk. Yet, the cross stands at the main Chervonohrad plaza in the present, echoing a palimpsest of the contested town's history. The Jewish history of Chervonohrad, on the other hand, remains invisible, as there are no artifacts and no holders of the tradition left to reinstate it in the town's built environment.

\section{CONCLUSION}

The demolition of Chervonohrad's Lenin statue, frequently seen as the precursor of the post-1991 and 2013-14 Lenin monument demolitions in Ukraine and around the former USSR, should not be seen as a simple political act representing a state-scale agenda. Instead, like many other monuments destroyed at the time of a historic rupture, the Lenin statue removal should be analyzed from the perspectives of local place politics and appropriation.

The Lenin monument demolition in Chervonohrad on the eve of the collapse of the Soviet Union should be viewed as a combined result of the town's location at the periphery of the USSR, the rupture of the 
administrative link with the Soviet centre, and the strike movements of local workers. The geographic and political location of Chervonohrad, peripheral to the central USSR authority, allowed for this historic event through changes in local authorities.

While the example of Chervonohrad may seem to be unique in its concatenation of events, complex circumstances stand behind many communist monument demolitions in the post-Soviet geographies. The still standing Karl Marx in Chemnitz, recent examples of the "war of monuments" between Baltic States and Russia (Burch and Smith 913-36), and the 201314 revolutionary events and Lenin statue demolitions in Ukraine pose more questions than give answers to researchers. The case of Chervonohrad suggests that joint interdisciplinary methodologies and small-scale case studies have the potential to provide answers.

\section{Works Cited}

Ahapov, V. L. "Vzaiemovidnosyny straikovoho shakhtars'koho i natsional'nodemokratychnoho rukhiv u 1991 r." Ukrains'kyi istorychnyi zhurnal, no. 4, 2011, pp. 23-40.

Birch, Sarah. "Electoral Behavior in Western Ukraine in National Elections and Referendums, 1989-91." Europe-Asia Studies, vol. 47, no. 7, Nov. 1995, pp. 114576.

Birgerson, Susanne M. After the Breakup of a Multi-Ethnic Empire: Russia, Successor States, and Eurasian Security. Praeger, 2002.

Bondaruk, S. "Shche odnu vymohu straikariv vykonano. Shcho dali?" Shakhtar Chervonohrada, 2 Aug. 1990, front page.

Burch, Stuart, and David J. Smith. "Empty Spaces and the Value of Symbols: Estonia's 'War of Monuments' from Another Angle." Europe-Asia Studies, vol. 59, no. 6, 2007, pp. 913-36.

"Demontazh pam"iatnyka Leninu v Chervonohradi." Filmed on 1 Aug. 1990. YouTube, uploaded by volsvyn, 28 Aug. 2012, http://www.youtube.com/watch?v=EYykAxGzLN8. Accessed 25 Oct. 2015.

Diener, Alexander and Joshua Hagen. "From Socialist to Post-Socialist Cities: Narrating the Nation Through Urban Space." Nationalities Papers, vol. 41, no. 4, 2013, pp. 487-514.

Forest, Benjamin, and Juliet Johnson. "Monumental Politics: Regime Type and Public Memory in Post-Communist States." Post-Soviet Affairs, vol. 27, no. 3, 2011, pp. 269-88.

---. "Unraveling the Threads of History: Soviet-Era Monuments and Post-Soviet National Identity in Moscow." Annals of the Association of American Geographers, vol. 92, no. 3, 2002, pp. 524-47.

Gaidai, Oleksandra. "Memoralization of Lenin: Legislation and Attitudes (On the Materials of Kyiv, Vinnytsia and Cherkasy Regions)." Kyiv-Mohyla Humanities Journal, no. 2, 2015, pp. 137-54. 
Hou, Jeffrey. Insurgent Public Space: Guerrilla Urbanism and the Remaking of the Contemporary Cities. Routledge, 2010.

Hrynyk, Halyna, and Olena Iarosh-Zamois'ka. Krystynopil' (1692-1951). IuEKS, 2010. Lane, David S. Soviet Society Under Perestroika. Routledge, 1992.

L., Mariia Akimivna. Personal interview. 25 July 2015.

Marchenko, V. D., and H. V. Kolobov. Trudova slava Chervonohrada. Kameniar, 1972.

Matthews, Mervyn. Privilege in the Soviet Union: A Study of Elite Life-Styles Under Communism. Routledge, 2012.

"Novyi Dvir. Chervonohrad-Solokiia." YouTube, uploaded by Wholesale TV 1opto, 15 Mar. 2015, http://www.youtube.com/watch?v=yIeRL r2hxs. Accessed 21 Oct. 2015.

Oleshko, K. "Prysiaha na virnist' ideiam velykoho Lenina." Shakhtar Chervonohrada, 3 Nov. 1977, front page.

"Protokol pozacherhovoi sesii pershoho demokratychnoho sklykannia Chervonohrads'koi mis'koi Rady narodnykh deputativ L'vivs'koi oblasti." 20 July 1990. Transcript.

"Protokol zasidannia 89-i sesii Verkhovnoi Rady Ukrains'koi Radians'koi Sotsialistychnoi Respubliky." Verkhovna Rada Ukrainy, 2 Aug. 1990, http://static.rada.gov.ua/zakon/skl1/BUL11/020890 89.htm. Accessed 13 Oct. 2015.

Przybylska, Lucyna. "Memorial Crosses in Poland: A Commonplace and Contested Element of Public Roads." Geografie, vol. 120, no. 4, 2015, pp. 508-26.

---. "Solidarity and Identity in Memorial Crosses in Gdańsk." International Journal of Humanities and Social Science, vol. 3, no. 6, March 2013, pp. 26-34.

Repa, Jan. "Analysis: Solidarity's Legacy." BBC News, 12 Aug. 2005, http://news.bbc.co.uk/2/hi/europe/4142268.stm. Accessed 25 Oct. 2017.

Rozluts'kyi, Vasyl'. "Vpershe v Ukraini." Provesen', no. 4-5, 2001, pp. 38-39.

Rusnachenko, Anatolii. "The Workers' and National-Democratic Movements in Contemporary Ukraine." Journal of Ukrainian Studies, vol. 18, no. 1-2, SummerWinter 1993, pp. 123-49.

Sh., Iryna. Personal interview. 25 July 2015.

Sidorov, Dmitri. "National Monumentalization and the Politics of Scale: The Resurrections of the Cathedral of Christ the Savior in Moscow." Annals of the Association of American Geographers, vol. 90, no. 3, Sept. 2000, pp. 548-72.

Zharchyns'ka, Ol'ha. "Chervonohrads'ki shakhtari pershymy povalyly Lenina." Visnyk, 20 Aug. 2010, http://archive.visnyk.lutsk.ua/2010/8/20/10498/. Accessed 25 Oct. 2015. 